\title{
Prognostic value of the S100B protein in newly diagnosed and recurrent glioma patients: a serial analysis
}

\author{
F. K. Holla ${ }^{1}$ T. J. Postma ${ }^{1}$ M. A. Blankenstein ${ }^{2}$ T. J. M. van Mierlo ${ }^{1}$ M. J. Vos $^{3}$ \\ E. M. Sizoo ${ }^{1}$ - M. de Groot ${ }^{1}$ - B. M. J. Uitdehaag ${ }^{1,4}$ • J. Buter ${ }^{5}$ - M. Klein ${ }^{6}$. \\ J. C. Reijneveld ${ }^{1}$ ·. J. J. Heimans ${ }^{1}$
}

Received: 31 March 2016 / Accepted: 3 July 2016 / Published online: 11 July 2016

(C) The Author(s) 2016. This article is published with open access at Springerlink.com

\begin{abstract}
The S100B protein is associated with brain damage and a breached blood-brain barrier. A previous pilot study showed that high serum levels of S100B are associated with shorter survival in glioma patients. The aim of our study was to assess the prognostic value in terms of survival and longitudinal dynamics of serum S100B for patients with newly diagnosed and recurrent glioma. We obtained blood samples from patients with newly diagnosed and recurrent glioma before the start (baseline) and at fixed time-points during temozolomide chemotherapy. S100B-data were dichotomized according to the upper limit of the reference value of $0.1 \mu \mathrm{g} / \mathrm{L}$. Overall survival (OS) was estimated with Kaplan-Meier curves and groups were compared with the $\log$ rank analysis. To correct for potential confounders a Cox regression analysis was used. We included 86 patients with newly-diagnosed and 27 patients with recurrent glioma. Most patients in both groups had baseline serum levels within normal limits. In the newly diagnosed patients we
\end{abstract}

\section{T. J. Postma}

tj.postma@vumc.nl

1 Department of Neurology, VU University Medical Center, PO Box 7057, 1007 MB Amsterdam, The Netherlands

2 Clinical Chemistry, VU University Medical Center, Amsterdam, The Netherlands

3 Department of Neurology, Medical Center Haaglanden, The Hague, The Netherlands

4 Epidemiology and Biostatistics, VU University Medical Center, Amsterdam, The Netherlands

5 Medical Oncology, VU University Medical Center, Amsterdam, The Netherlands

6 Medical Psychology, VU University Medical Center, Amsterdam, The Netherlands found no significant difference in OS between the group of patients with S100B levels $>0.1 \mu \mathrm{g} / \mathrm{L}$ at baseline compared to those with $<0.1 \mu \mathrm{g} / \mathrm{L}$. In the patients with recurrent glioma we found a significantly shorter OS for patients with raised levels. In both groups, S100B values did not change significantly throughout the course of the disease. Serum S100B levels do not seem to have prognostic value in newly diagnosed glioma patients. In recurrent glioma patients S100B might be of value in terms of prognostication of survival.

Keywords Glioma $\cdot$ S100B $\cdot$ Survival $\cdot$

Chemotherapy $\cdot$ Prognosis

\section{Introduction}

Gliomas are the most common primary brain tumors in adults with a histological grade that ranges from low (WHO I, II) to high grade (WHO III, IV) [1]. Despite different treatment regimens, such as radio- and chemotherapy, which have evolved over the past decade, survival is still limited. Various prognostic factors have been identified, such as age, histology, extent of resection, corticosteroid use, and Karnofsky Performance Status (KPS) [2-7]. Currently the role of the genetic profile of gliomas is extensively being investigated and seems to be a strong prognostic factor in survival and treatment response in glioma patients [8-10]. However, an easy to use serum biomarker to predict the prognosis in glioma patients would still be an asset for patient care. Serum levels of the S100B protein may be valuable in this respect.

The S100B protein is one of the most studied markers of central nervous system (CNS) pathology. This cytoplasmic $\mathrm{Ca}^{2+}$-binding protein is highly expressed in the CNS where it is primarily secreted by astrocytes and other glial cell types such as Schwann cells and oligodendrocytes [11-13]. 
This protein is also widely distributed in tissues outside the nervous system, such as melanocytes, chondrocytes, skeletal muscle cells and adipose tissue [14-17].

Astrocytes leak and actively secrete S100B into the extracellular environment during metabolic stress, leading to raised levels in the cerebrospinal fluid (CSF) [18]. When the blood-brain barrier (BBB) is breached, the protein is subsequently released into the serum. Serum S100B is a suggested marker for BBB integrity, because levels are also raised after chemically opening the $\mathrm{BBB}$ in the absence of cerebral damage [19].

In clinical practice raised serum levels of $\mathrm{S} 100 \mathrm{~B}$ have been found in numerous neurological disorders, such as traumatic brain injury and acute stroke. In these conditions raised serum S100B levels are positively correlated with unfavourable neurological outcome, mortality and imaging characteristics [20-29]. Furthermore, serum S100B has an established role in the management of melanoma, especially in the prediction of response to systemic therapy [30-33]. Raised serum levels of the protein have a potential role in the prediction and detection of brain metastasis in lung cancer patients as well [34].

In glioma patients little is known about the prognostic value of serum S100B and its longitudinal behaviour during the course of the disease. Raised serum levels have been documented in glioblastoma patients [35]. Furthermore, a former pilot study showed a correlation between high serum S100B concentrations and a shorter survival in a small population of glioma patients [36]. Based on these results, we hypothesize that serum S100B can be helpful in predicting prognosis in glioma patients.

The aim of this study was to prospectively evaluate the prognostic value and the longitudinal dynamics in terms of overall survival (OS) of serum S100B in patients with newly diagnosed and recurrent glioma during treatment with chemotherapy.

\section{Patients and methods}

Between September 2004 and January 2013 patients with histological proven, newly diagnosed or recurrent glioma who were scheduled for chemotherapy treatment and who visited the Neurology out-patient clinic of our institution, were included into a prospective study on the evaluation of side effects of chemotherapy. Informed consent was obtained by the treating physician and the protocol of this study was approved by the local Ethics Committee.

\section{Newly diagnosed glioma}

Patients in this group were eligible if they were diagnosed with histologically proven glioma, had a good performance status, and were scheduled for postoperative treatment with concurrent radiotherapy (60 Gy in 30 fractions of 2 Gy) and chemotherapy (temozolomide $75 \mathrm{mg} / \mathrm{m}^{2}, 5$ days/week for 6 weeks during radiotherapy) followed by six adjuvant courses of chemotherapy in the form of oral temozolomide $150-200 \mathrm{mg} / \mathrm{m}^{2}$ in cycles of 5 days in 4 weeks [37]. Serum samples were obtained at baseline (before the concomitant phase), before the adjuvant phase, and every three cycles thereafter until progressive disease or chemotherapy-induced toxicity was apparent. From patients that had completed six adjuvant courses without radiological and/or clinical progression, serum samples were also acquired at 3 and 7 months after treatment.

\section{Recurrent glioma}

For this group, patients were included who were diagnosed with radiologically and/or surgically confirmed tumor recurrence of a previously histologically confirmed glioma, and who were scheduled for treatment with chemotherapy.

Chemotherapy consisted of oral temozolomide in two possible regimens: a short cycle of 5 consecutive days in 4 weeks in doses of $150-200 \mathrm{mg} / \mathrm{m}^{2}$, or a long cycle of 21 consecutive days in 4 weeks (' 3 weeks on, 1 week off') in doses of $75 \mathrm{mg} / \mathrm{m}^{2}$.

If patients previously had been treated with temozolomide, they received PCV: a combination chemotherapy of $110 \mathrm{mg} / \mathrm{m}^{2}$ oral lomustine (CCNU) on day 1 , followed by $1.4 \mathrm{mg} / \mathrm{m}^{2}$ intravenous vincristine on day 8 , and $60 \mathrm{mg} / \mathrm{m}^{2}$ of oral procarbazine from day 8 until 23 with repeated administration of $1.4 \mathrm{mg} / \mathrm{m}^{2}$ intravenous vincristine on day 29 . Cycles were repeated until clinical and/or radiological progression or chemotherapy-induced toxicity was apparent.

Serum samples in this group were obtained at baseline (before start of first cycle) and every three cycles thereafter during chemotherapy treatment.

\section{Chemical analysis}

All patients were seen in a single clinic. Blood was collected at the physician's office by venous puncture and transported immediately to the adjacent clinical chemistry laboratory where it was centrifuged, aliquoted, frozen and stored at $-20^{\circ} \mathrm{C}$ until assay. The entire procedure was completed within $2 \mathrm{~h}$ from phlebotomy.

Serum S100B was measured by the commercially available immunologic assay Elecsys S100 (Roche/Cobas ${ }^{\circledR}$ ) with a detection limit of $<0.005 \mu \mathrm{g} / \mathrm{L}$. Intra-assay variation at 0.06 and $0.31 \mu \mathrm{g} / \mathrm{L}$ was 1.9 and $1.0 \%$ respectively $(\mathrm{n}=10)$. Inter-assay variation at 0.197 and $2.46 \mu \mathrm{g} / \mathrm{L}$ was 1.6 and $5.6 \%$ respectively $(n=16$; three lots of controls). All samples were analyzed without knowledge of the clinical status of the patient. Data were dichotomized with a cut off value 
of $0.1 \mu \mathrm{g} / \mathrm{L}$, which is considered to be the estimated upper limit of the reference range in serum [38-40].

\section{Definition of outcome variables}

Patients' clinical records were reviewed to obtain information concerning clinical and survival data. OS was defined as the interval between the date of baseline blood sampling and date of death. Tumor progression was defined according to the RANO criteria [41]. Age, tumor grade, baseline KPS and corticosteroid use were included as co-variables.

\section{Statistical analysis}

Kaplan-Meier curves were used to estimate OS times. To calculate significance between survival curves a log-rank test was used. A Cox proportional hazard analysis was used to assess the prognostic value of serum S100B, corrected for potential confounders. To calculate a significant change of S100B value during follow up a Mann-Whitney $U$ test was used. A $p$-value of $<0.05$ was used to determine significance. The analyses were performed with SPSS software (version 20.0).

\section{Results}

\section{Patient characteristics}

Tables 1 and 2 list the patient characteristics for the newly diagnosed and recurrent glioma patient groups respectively.

Ninety-seven patients were newly diagnosed with glioma, had undergone cranial surgery and were scheduled for postoperative chemo-radiation therapy. In 11 patients a baseline blood sample could not be obtained and were therefore excluded from further analysis, resulting in 86 included patients. The median OS since baseline blood sampling was 14 months (range 2-60). As of August 2013, 25 out of 86 patients had not died and were thus censored to this date.

Twenty-seven patients were diagnosed with recurrent glioma according to the RANO criteria and were scheduled for treatment with chemotherapy. Tumor recurrence was confirmed by MR imaging in 15 patients, and histological confirmed in 12 patients. Twenty patients were treated for their first recurrence and seven patients for their second. All patients had previously undergone surgical resection or stereotactic biopsy, of which six patients were re-operated once and five patients twice. Twenty patients received radiotherapy in an earlier stage of disease and five patients were already treated with chemotherapy of which one patient was treated for another malignancy (sigmoid carcinoma).
Table 1 Patient characteristics newly diagnosed glioma group

\begin{tabular}{|c|c|}
\hline Characteristic & $\begin{array}{l}\text { Number of } \\
\text { patients }(n=86)\end{array}$ \\
\hline Male/female ratio & $59 / 27$ \\
\hline Median age $(\mathrm{y} ; \text { range })^{\mathrm{a}}$ & $56(18-78)$ \\
\hline Baseline corticosteroids yes $/$ no $^{b}$ & $23 / 63$ \\
\hline Median baseline KPS (range) & $90(50-100)$ \\
\hline \multicolumn{2}{|l|}{ Histology } \\
\hline GBM & 85 \\
\hline O/A III & 1 \\
\hline \multicolumn{2}{|l|}{ Type of surgery } \\
\hline Resection & 78 \\
\hline Stereotactic biopsy & 8 \\
\hline Median total dose rth (Gy) & $60(42-60)$ \\
\hline Median number TMZ courses $(n)^{d}$ & $6(0-13)$ \\
\hline $\begin{array}{l}\text { Median time primary diagnosis-baseline } \\
\text { S100B (days) }\end{array}$ & $18(6-56)$ \\
\hline \multicolumn{2}{|c|}{$\begin{array}{l}K P S \text { Karnofsky Performance Score, rth radiotherapy, TMZ } \\
\text { temozolomide, } G B M \text { glioblastoma, } O / A \text { oligo-astrocytoma }\end{array}$} \\
\hline \multicolumn{2}{|l|}{${ }^{\mathrm{a}}$ Age at primary diagnosis } \\
\hline \multicolumn{2}{|l|}{${ }^{\mathrm{b}}$ Corticosteroid $=$ oral dexamethason } \\
\hline \multicolumn{2}{|l|}{${ }^{\mathrm{C}}$ Type of surgery at primary diagnosis } \\
\hline${ }^{\mathrm{d}}$ Adjuvant TMZ courses & \\
\hline
\end{tabular}

The median survival after baseline blood sampling was 12 months (1-74) with 4 out of 27 patients censored.

\section{Serum S100B measurements}

In the newly diagnosed group a median number of three serum samples (range 1-6) was obtained per patient. The median baseline serum S100B value was $0.049 \mu \mathrm{g} / \mathrm{L}$ (range $0.015-0.459)$. Seven patients $(8 \%)$ had levels above the upper limit of the reference range of $0.1 \mu \mathrm{g} / \mathrm{L}$, all diagnosed with glioblastoma multiforme with two patients demonstrating remarkably high serum levels of 0.313 and $0.459 \mu \mathrm{g} / \mathrm{L}$. Median serum levels did not change significantly during follow-up (Fig. 1a). Age did not seem to interfere with $\mathrm{S} 100 \mathrm{~B}$ values as well $(\mathrm{p}=0.557$, independent $t$ test).

The median number of serum samples obtained in the recurrent group was 2 (range 1-7) and the median baseline $\mathrm{S} 100 \mathrm{~B}$ value was $0.064 \mu \mathrm{g} / \mathrm{L}(0.020-0.430)$. Seven patients (26\%) had levels exceeding the reference value, of which six had been diagnosed with glioblastoma multiforme and one patient with oligodendroglioma WHO III. There was one patient with a high serum level of $0.430 \mu \mathrm{g} / \mathrm{L}$, who had been diagnosed with glioblastoma multiforme. As in the newly diagnosed group no significant changes were found in median serum S100b levels during treatment with chemotherapy (Fig. 1b). There was no significant difference in age between these two groups ( $\mathrm{p}=0.831$, independent $t$ test). 
Table 2 Patient characteristics recurrent glioma group

\begin{tabular}{|c|c|}
\hline Characteristic & $\begin{array}{l}\text { Number } \\
\text { of patients } \\
(\mathrm{n}=27)\end{array}$ \\
\hline Male/female ratio & $17 / 10$ \\
\hline Median age $(\mathrm{y} ; \text { range })^{\mathrm{a}}$ & $47(22-66)$ \\
\hline Baseline corticosteroids yes $/$ no $^{b}$ & $13 / 14$ \\
\hline Median baseline KPS (range) & $80(50-100)$ \\
\hline \multicolumn{2}{|l|}{ Histology } \\
\hline A II-A III-O II-O III-O IV - -O/A II-O/A III-GBM & $\begin{array}{c}3-4-2-3-1- \\
1-2-11\end{array}$ \\
\hline \multicolumn{2}{|l|}{ Type of chemotherapy received } \\
\hline TMZ 5/28/TMZ 3 weeks on, 1 week off/PCV & $22 / 4 / 1$ \\
\hline Median number chemotherapy courses (n; range) & $6(1-18)$ \\
\hline $\begin{array}{l}\text { Median time primary diagnosis - baseline S100B } \\
\text { (mo, range) }\end{array}$ & $26(1-223)$ \\
\hline \multicolumn{2}{|c|}{$\begin{array}{l}\text { KPS Karnofsky Performance Score, rth radiotherapy, } T M Z \\
\text { temozolomide, } P C V \text { procarbazine, CCNU and vincristine, } \\
\text { astrocytoma, } O \text { oligodendroglioma, } O / A \text { oligo-astrocytoma, } G B M \\
\text { glioblastoma }\end{array}$} \\
\hline \multicolumn{2}{|l|}{${ }^{\mathrm{a}}$ Age at inclusion date } \\
\hline \multicolumn{2}{|l|}{${ }^{\mathrm{b}}$ Corticosteroid $=$ oral dexamethason } \\
\hline${ }^{\mathrm{c}}$ Glioblastoma with oligodendroglial ce & \\
\hline
\end{tabular}

\section{Survival analysis}

In the newly diagnosed group one of the two patients demonstrating the highest serum levels showed a relatively short survival ( 8 months) since baseline blood sampling. However, the other patient was still alive as of August 2013 with a survival of 23 months from baseline blood sampling.

The patient demonstrating the highest serum level in the recurrent group also showed a relatively short survival compared to the median survival since baseline blood sampling (6 vs. 12 months, respectively). Only one patient demonstrated a shorter survival of 1 month (baseline serum S100B: $0.107 \mu \mathrm{g} / \mathrm{L}$ ).

When patients in both groups were dichotomized by the estimated upper limit of the reference range of $0.1 \mu \mathrm{g} / \mathrm{L}$, no significant difference in survival was found in the newly diagnosed group.

In the recurrent group a significantly shorter survival of median 4 months (range $1-10)$ was found for patients $(n=7)$ with serum levels $>0.1 \mu \mathrm{g} / \mathrm{L}$ compared to 16 months median survival (range 3-69) for patients $(n=20)$ with serum levels $<0.1 \mu \mathrm{g} / \mathrm{L}$ ( $\log$ rank-test, $\mathrm{p}=0.000$, Fig. 2). This remained significant after correction for age, tumor grade (dichotomized according to WHO high grade vs. low grade), KPS at baseline and corticosteroid use at baseline with Cox proportional hazard analysis (hazard ratio $4.1,95 \%$ confidence interval 1.1-15.2).

\section{Discussion}

In the current study we found that the majority of newly diagnosed and recurrent glioma patients have serum S100B levels within normal limits. The median serum levels at baseline for the newly diagnosed and recurrent groups were respectively 0.049 and $0.064 \mu \mathrm{g} / \mathrm{L}$. These findings are fairly in line with other studies, which also found median values within the reference range in glioma patients at different stages of disease [36, 42-44]. Furthermore, no significant change over the course of treatment was found in both patient groups.

Although a significantly shorter survival was found for patients with raised levels in the recurrent glioma group, this was not found for the, much larger, newly diagnosed glioma group.

Regarding the correlation of serum S100B levels and survival in glioma patients few data are available in literature. Mutlu et al. found no significant association between pretreatment serum S100B values and OS in patients $(n=27)$, who were recently diagnosed with glioblastoma [43]. These results are confirmed by our findings in the newly diagnosed glioma group. Vos et al. found an association between serum levels above $0.09 \mu \mathrm{g} / \mathrm{L}$ and a shorter survival in glioma patients at different stages of treatment and disease $(n=20)$ [36]. These results are in line with the findings in our recurrent group. We have no clear explanation for this phenomenon. However, the number of patients in both the recurrent group in our study and the group investigated by Vos et al. is small and in various stages of disease, and should thus be interpreted with caution.

Several hypotheses concerning raised serum S100B levels in glioma patients have been postulated:

(1) proliferating brain tumors can cause damage to astrocytes by causing a disruption of cell integrity, leading to an increased release of S100B, (2) disruption of the BBB also leads to an increase in serum S100B levels, even in absence of cerebral damage $[19,45,46]$. (3) craniotomy itsels may lead to higher S100B levels [47].

Marchi et al. published a mathematical model in which it is postulated that maximum serum levels achievable after BBB-failure are around $0.34 \mu \mathrm{g} / \mathrm{L}$ and thus, levels exceeding these values are probably due to other factors such as non-CNS release or concomitant brain damage [46].

Breaching of the BBB can be assessed by the appearance of contrast enhancement on MRI, which is especially apparent in high grade gliomas. All patients in our study showed contrast enhancement on MRI, indicating breaching of BBB. According to the model of Marchi et al. it would seem logical that the majority of patients would have elevated serum S100B values, however most patients showed serum levels within normal limits throughout various stages of disease. 
Fig. 1 Longitudinal dynamics for median serum S100B values during the course of therapy for a newly diagnosed glioma and $\mathbf{b}$ recurrent glioma. Error bars represent $95 \%$ confidence intervals
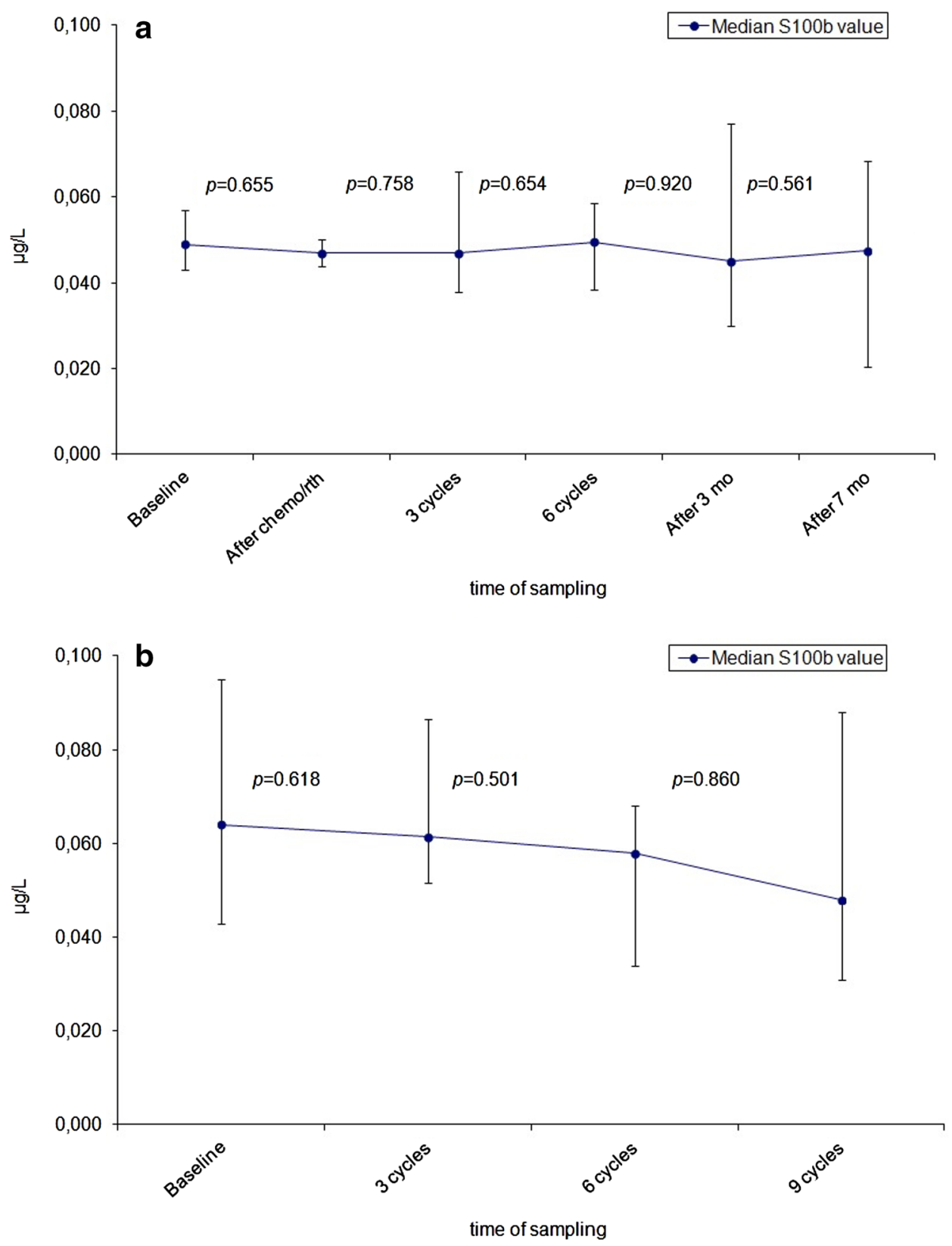

Furthermore, no clear correlation (data not shown) could be found between the degree of contrast enhancement and serum levels. In contrast, brain damage and disruption of the BBB caused by traumatic brain injury and acute stroke does seem to lead to raised serum S100B levels which is correlated to clinical outcome and mortality [22, 25, 29]. It remains unclear why glioma patients do not show significant elevation of serum levels.

Syeda et al. describe temporarily ( $<7$ days) high serum levels of S100B in patients who underwent craniotomy for a brain tumor, suggesting that these values are probably due to surgically induced tissue damage [47]. In our study the median interval between baseline blood sampling and last surgery was 18 and 247 days, in newly diagnosed and recurrent glioma patients, respectively, which is significantly longer than the interval described in literature. Furthermore, we found no consistent trend in S100B levels in patients with resection vs. biopsy in this study.

There are several limitations to this study. First, blood sampling was ceased when clinical and/or radiological progression was apparent. As such, it was not possible to study the values of serum S100B after tumor progression. Therefore, it is recommended that serum measurements are continued in patients that show clinical and/or radiological progression and subsequently switch to alternative treatments. Second, patients in the recurrent group showed heterogeneity regarding the stages of disease and previous treatment, which may have influenced survival data and/or 
Fig. 2 Kaplan-Meier curves for overall survival dichotomized according to the upper limit of the reference range of $0.100 \mu \mathrm{g} / \mathrm{L}$ for a newly diagnosed glioma and $\mathbf{b}$ recurrent glioma
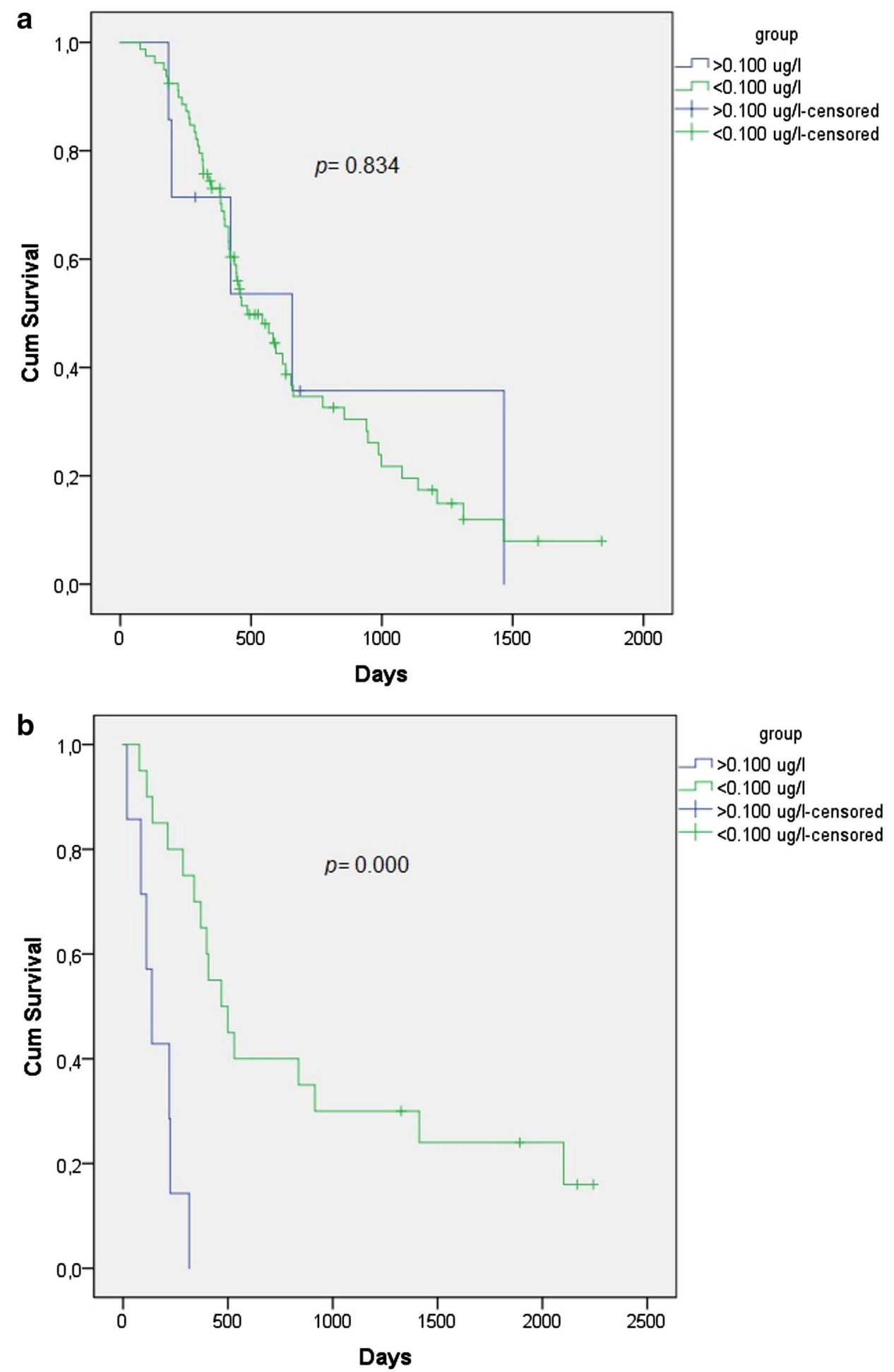

serum S100B levels. Third, the genetic profile of our glioma patients was not assessed as a confounding factor in this study, which may have biased the results concerning the prognostic value of serum S100B. Last, as mentioned earlier, the number of patients in the recurrent group was low $(n=27)$, which may have led to biased results.
In conclusion, the majority of glioma patients have normal serum S100B values which remains within the normal limits throughout the course of the disease. Serum S100B does not seem to have prognostic value in newly diagnosed glioma patients. In recurrent glioma patients S100B might be of value in terms of prognostication of survival. 
Acknowledgments The authors gratefully acknowledge Joop Nijhof for performing the S100B assays.

\section{Compliance with ethical standards}

Conflict of interest The authors declare that they have no conflict of interest.

Informed consent Informed consent was obtained from all participants included in the study.

Statement of human interest All procedures performed in studies involving human participants were in accordance with the ethical standards of the institutional and/or national research committee and with the 1964 Helsinki declaration and its later amendments or comparable ethical standards.

Open Access This article is distributed under the terms of the Creative Commons Attribution 4.0 International License (http://creativecommons.org/licenses/by/4.0/), which permits unrestricted use, distribution, and reproduction in any medium, provided you give appropriate credit to the original author(s) and the source, provide a link to the Creative Commons license, and indicate if changes were made.

\section{References}

1. Louis DN, Ohgaki H, Wiestler OD, Cavenee WK, Burger PC, Jouvet A et al (2007) The 2007 WHO classification of tumours of the central nervous system. Acta Neuropathol 114(2):97-109

2. Nuno M, Birch K, Mukherjee D, Sarmiento JM, Black KL, Patil CG (2013) Survival and prognostic factors of anaplastic gliomas. Neurosurgery 73(3):458-465

3. Sanai N, Berger MS (2008) Glioma extent of resection and its impact on patient outcome. Neurosurgery 62(4):753-764

4. Back MF, Ang ELL, Ng WH, See SJ, Lim CCT, Chan SP et al (2007) Improved median survival for glioblastoma multiforme following introduction of adjuvant temozolomide chemotherapy. Ann Acad Med Singap 36(5):338-342

5. Donato V, Papaleo A, Castrichino A, Banelli E, Giangaspero F, Salvati M et al (2007) Prognostic implication of clinical and pathologic features in patients with glioblastoma multiforme treated with concomitant radiation plus temozolomide. Tumori 93(3):248-256

6. Curran WJJ, Scott CB, Horton J, Nelson JS, Weinstein AS, Fischbach AJ et al (1993) Recursive partitioning analysis of prognostic factors in three Radiation Therapy Oncology Group malignant glioma trials. J Natl Cancer Inst 85(9):704-710

7. Cairncross G, Berkey B, Shaw E, Jenkins R, Scheithauer B, Brachman D et al (2006) Phase III trial of chemotherapy plus radiotherapy compared with radiotherapy alone for pure and mixed anaplastic oligodendroglioma: Intergroup Radiation Therapy Oncology Group Trial 9402. J Clin Oncol 24(18):2707-2714

8. Hegi ME, Diserens AC, Gorlia T, Hamou MF, de Tribolet N, Weller $M$ et al (2005) MGMT gene silencing and benefit from temozolomide in glioblastoma. N Engl J Med 352(10):997-1003

9. Cohen AL, Colman H (2015) Glioma biology and molecular markers. Cancer Treat Res 163:15-30

10. Speirs CK, Simpson JR, Robinson CG, DeWees TA, Tran DD, Linette $G$ et al (2015) Impact of $1 p / 19 q$ codeletion and histology on outcomes of anaplastic gliomas treated with radiation therapy and temozolomide. Int J Radiat Oncol Biol Phys 91(2):268-276

11. Ludwin SK, Kosek JC, Eng LF (1976) The topographical distribution of S-100 and GFA proteins in the adult rat brain: an immunohistochemical study using horseradish peroxidaselabelled antibodies. J Comp Neurol 165(2):197-207

12. Brockes JP, Fields KL, Raff MC (1979) Studies on cultured rat Schwann cells. I. Establishment of purified populations from cultures of peripheral nerve. Brain Res 165(1):105-118

13. Rickmann M, Wolff JR (1995) S100 protein expression in subpopulations of neurons of rat brain. Neuroscience 67(4):977-991

14. Cocchia D, Michetti F, Donato R (1981) Immunochemical and immuno-cytochemical localization of S-100 antigen in normal human skin. Nature 294(5836):85-87

15. Stefansson K, Wollmann RL, Moore BW, Arnason BG (1982) S-100 protein in human chondrocytes. Nature 295(5844):63-64

16. Tubaro C, Arcuri C, Giambanco I, Donato R (2010) S100B protein in myoblasts modulates myogenic differentiation via NFkappaB-dependent inhibition of MyoD expression. J Cell Physiol 223(1):270-282

17. Michetti F, Dell'Anna E, Tiberio G, Cocchia D (1983) Immunochemical and immunocytochemical study of S-100 protein in rat adipocytes. Brain Res 262(2):352-356

18. Gerlach R, Demel G, Konig HG, Gross U, Prehn JHM, Raabe A et al (2006) Active secretion of S100B from astrocytes during metabolic stress. Neuroscience 141(4):1697-1701

19. Kapural M, Krizanac-Bengez L, Barnett G, Perl J, Masaryk T, Apollo D et al (2002) Serum S-100beta as a possible marker of blood-brain barrier disruption. Brain Res 940(1-2):102-104

20. Abraha HD, Butterworth RJ, Bath PM, Wassif WS, Garthwaite J, Sherwood RA (1997) Serum S-100 protein, relationship to clinical outcome in acute stroke. Ann Clin Biochem 34(Pt 5):546-50

21. Sanchez-Pena P, Pereira AR, Sourour NA, Biondi A, Lejean L, Colonne $\mathrm{C}$ et al (2008) S100B as an additional prognostic marker in subarachnoid aneurysmal hemorrhage. Crit Care Med 36(8):2267-2273

22. Mercier E, Boutin A, Lauzier F, Fergusson DA, Simard JF, Zarychanski R et al (2013) Predictive value of S-100beta protein for prognosis in patients with moderate and severe traumatic brain injury: systematic review and meta-analysis. BMJ 346:f1757

23. Wiesmann M, Steinmeier E, Magerkurth O, Linn J, Gottmann D, Missler U (2010) Outcome prediction in traumatic brain injury: comparison of neurological status, CT findings, and blood levels of S100B and GFAP. Acta Neurol Scand 121(3):178-185

24. Gradisek P, Osredkar J, Korsic M, Kremzar B (2012) Multiple indicators model of long-term mortality in traumatic brain injury. Brain Inj 26(12):1472-1481

25. Foerch C, Singer OC, Neumann-Haefelin T, du Mesnil de Rochemont R, Steinmetz H, Sitzer M (2005) Evaluation of serum $\mathrm{S} 100 \mathrm{~B}$ as a surrogate marker for long-term outcome and infarct volume in acute middle cerebral artery infarction. Arch Neurol 62(7):1130-1134

26. Sienkiewicz-Jarosz H, Galecka-Wolska M, Bidzinski A, Turzynska D, Sobolewska A, Lipska B et al (2009) Predictive value of selected biochemical markers of brain damage for functional outcome in ischaemic stroke patients. Neurol Neurochir Pol 43(2):126-133

27. Moritz S, Warnat J, Bele S, Graf BM, Woertgen C (2010) The prognostic value of NSE and S100B from serum and cerebrospinal fluid in patients with spontaneous subarachnoid hemorrhage. J Neurosurg Anesthesiol 22(1):21-31

28. Gonzalez-Garcia S, Gonzalez-Quevedo A, Fernandez-Concepcion O, Pena-Sanchez M, Menendez-Sainz C, Hernandez-Diaz $Z$ et al (2012) Short-term prognostic value of serum neuron specific enolase and S100B in acute stroke patients. Clin Biochem 45(16-17):1302-1307

29. Dassan P, Keir G, Brown MM (2009) Criteria for a clinically informative serum biomarker in acute ischaemic stroke: a review of S100B. Cerebrovasc Dis 27(3):295-302 
30. Martenson ED, Hansson LO, Nilsson B, von Schoultz E, Mansson Brahme E, Ringborg U et al (2001) Serum S-100b protein as a prognostic marker in malignant cutaneous melanoma. J Clin Oncol 19(3):824-831

31. Kruijff S, Bastiaannet E, Brouwers AH, Nagengast WB, Speijers MJ, Suurmeijer AJH et al (2012) Use of S-100B to evaluate therapy effects during bevacizumab induction treatment in AJCC stage III melanoma. Ann Surg Oncol 19(2):620-626

32. Hamberg AP, Korse CM, Bonfrer JM, de Gast GC (2003) Serum $\mathrm{S} 100 \mathrm{~B}$ is suitable for prediction and monitoring of response to chemoimmunotherapy in metastatic malignant melanoma. Melanoma Res 13(1):45-49

33. Kluger HM, Hoyt K, Bacchiocchi A, Mayer T, Kirsch J, Kluger $Y$ et al (2011) Plasma markers for identifying patients with metastatic melanoma. Clin Cancer Res 17(8):2417-2425

34. Vogelbaum MA, Masaryk T, Mazzone P, Mekhail T, Fazio V, McCartney S et al (2005) S100beta as a predictor of brain metastases: brain versus cerebrovascular damage. Cancer 104(4):817-824

35. Lyubimova NV, Toms MG, Popova EE, Bondarenko YV, Krat VB, Kushlinskii NE (2011) Neurospecific proteins in the serum of patients with brain tumors. Bull Exp Biol Med 150(6):732-734

36. Vos MJ, Postma TJ, Martens F, Uitdehaag BMJ, Blankenstein MA, Vandertop WP et al (2004) Serum levels of S-100B protein and neuron-specific enolase in glioma patients: a pilot study. Anticancer Res 24(4):2511-2514

37. Stupp R, Mason WP, van den Bent MJ, Weller M, Fisher B, Taphoorn MJB et al (2005) Radiotherapy plus concomitant and adjuvant temozolomide for glioblastoma. N Engl J Med 352(10):987-996

38. Wiesmann M, Missler U, Gottmann D, Gehring S (1998) Plasma $\mathrm{S}-100 \mathrm{~b}$ protein concentration in healthy adults is age- and sexindependent. Clin Chem 44(5):1056-1058
39. Portela LVC, Tort ABL, Schaf DV, Ribeiro L, Nora DB, Walz R et al (2002) The serum S100B concentration is age dependent. Clin Chem 48(6 Pt 1):950-952

40. van Munster BC, Korevaar JC, Korse CM, Bonfrer JM, Zwinderman AH, de Rooij SE (2010) Serum S100B in elderly patients with and without delirium. Int J Geriatr Psychiatry 25(3):234-239

41. Wen PY, Macdonald DR, Reardon DA, Cloughesy TF, Sorensen AG, Galanis E et al (2010) Updated response assessment criteria for high-grade gliomas: response assessment in neuro-oncology working group. J Clin Oncol 28(11):1963-1972

42. Brommeland T, Rosengren L, Fridlund S, Hennig R, Isaksen V (2007) Serum levels of glial fibrillary acidic protein correlate to tumour volume of high-grade gliomas. Acta Neurol Scand 116(6):380-384

43. Ilhan-Mutlu A, Wagner L, Widhalm G, Wohrer A, Bartsch S, Czech T et al (2013) Exploratory investigation of eight circulating plasma markers in brain tumor patients. Neurosurg Rev 36(1):45-55

44. Rajendra A, Spinella PC, Drott HR, Dominguez TE, Sutton L, Helfaer M (2004) S-100beta protein-serum levels in children with brain neoplasms and its potential as a tumor marker. J Neurooncol 67(3):345-349

45. Kanner AA, Marchi N, Fazio V, Mayberg MR, Koltz MT, Siomin V et al (2003) Serum S100beta: a noninvasive marker of bloodbrain barrier function and brain lesions. Cancer 97(11):2806-2813

46. Marchi N, Cavaglia M, Fazio V, Bhudia S, Hallene K, Janigro D (2004) Peripheral markers of blood-brain barrier damage. Clin Chim Acta 342(1-2):1-12

47. Syeda T, Muhammad Hashim AS, Rizvi HA, Hadi SM (2013) Serum S100B in patients with brain tumours undergoing craniotomy. J Coll Physicians Surg Pak 23(2):112-115 